\title{
Replicated associations of TNFAIP3, TNIP1 and ETS1 with systemic lupus erythematosus in a southwestern Chinese population
}

\author{
Hua Zhong ${ }^{1,4+}$, Xiao-lan Li ${ }^{2,3^{*}}{ }$, Ming Li ${ }^{1,5}$, Li-xia Hao ${ }^{2,3}$, Rong-wei Chen ${ }^{2,3}$, Kun Xiang ${ }^{1,5}$, Xue-bin Qi $i^{1}$, Runlin Z Ma ${ }^{4^{*}}$ \\ and Bing Su${ }^{1 *}$
}

\begin{abstract}
Introduction: Recent genome-wide and candidate gene association studies in large numbers of systemic lupus erythematosus (SLE) patients have suggested approximately 30 susceptibility genes. These genes are involved in three types of biological processes, including immune complex processing, toll-like receptor function and type I interferon production, and immune signal transduction in lymphocytes, and they may contribute to the pathogenesis of SLE. To better understand the genetic risk factors of SLE, we investigated the associations of seven SLE susceptibility genes in a Chinese population, including FCGR3A, FCGR2A, TNFAIP3, TLR9, TREX1, ETS1 and TNIP1.

Methods: A total of 20 SNPs spanning the seven SLE susceptibility genes were genotyped in a sample of 564 unrelated SLE patients and 504 unrelated healthy controls recruited from Yunnan, southwestern China. The associations of SNPs with SLE were assessed by statistical analysis.

Results: Five SNPS in two genes (TNFAIP3 and ETS1) were significantly associated with SLE (corrected $P$ values ranging from 0.03 to $5.5 \times 10^{-7}$ ). Through stratified analysis, TNFAIP3 and ETS1 showed significant associations with multiple SLE subphenotypes (such as malar rash, arthritis, hematologic disorder and antinuclear antibody) while TNIP1 just showed relatively weak association with onset age. The associations of the SNPs in the other four genes were not replicated.
\end{abstract}

Conclusions: The replication analysis indicates that TNFAIP3, ETS1 and TNIP1 are probably common susceptibility genes for SLE in Chinese populations, and they may contribute to the pathogenesis of multiple SLE subphenotypes.

\section{Introduction}

Systemic lupus erythematosus (SLE) is a chronic autoimmune disease with marked clinical heterogeneity. The integral components of SLE pathology - including abnormal function of $\mathrm{B}$ cells and $\mathrm{T}$ cells that generates autoreactive lymphocytes and responses to many selfantigens, the perpetual production of a broad variety of autoantibodies that cause incomplete clearance and subsequent tissue deposition of immune complexes, the

\footnotetext{
* Correspondence: xInli@yahoo.com; rlma@genetics.ac.cn; sub@mail.kiz.ac.cn + Contributed equally

${ }^{1}$ State Key Laboratory of Genetic Resources and Evolution, Kunming Institute of Zoology, Chinese Academy of Sciences, Kunming, Yunnan 650223, China 2Department of Dermatology and Rheumatology, The Affiliated Yan'an Hospital of Kunming Medical University, Kunming, Yunnan 650051, China Full list of author information is available at the end of the article
}

activation of complement and defective cellular apoptosis that generate a pool of potential autoantigens, and the expression of proinflammatory cytokines - all result in intense inflammation and multiple organ damage

Patients can be diagnosed as having SLE when they meet any four of 11 American College of Rheumatology classification criteria [1,2]. Genetic factors have been demonstrated to contribute to the susceptibility of SLE because of familial clustering [3-5] and increased concordance in monozygotic twins [6,7]. Since the 1970s, genetic analyses have been conducted to seek the susceptibility genes in SLE patients [8]. Especially, in the past 5 years, genome-wide association (GWA) and casecontrol studies in a large number of SLE patients have significantly expanded our understanding of the genetic

\section{Biomed Central}

(c) 2011 Zhong et al.; licensee BioMed Central Ltd. This is an open access article distributed under the terms of the Creative Commons Attribution License (http://creativecommons.org/licenses/by/2.0), which permits unrestricted use, distribution, and reproduction in any medium, provided the original work is properly cited. 
basis of SLE [8-20]. Approximately 30 genes have been identified as playing important roles in SLE pathogenesis, and most of these genes have been shown to act in three types of biological processes: immune complex processing, toll-like receptor (TLR) function and type I interferon production, and immune signal transduction in lymphocytes $[8,18,21,22]$. These findings have revealed many robust associations and the related biological pathways involved in this complex disease. As an unusually heterogeneous disease, however, the genetic risk factors of SLE are yet to be fully dissected by conducting more studies, especially replications in populations with different ethnic backgrounds.

Among the top candidates for SLE susceptibility genes, Fc $\gamma$ receptors (FCGRs) are involved in immune complex processing and are associated with SLE pathogenesis. Particularly, FCGR2A and FCGR3A possess functional variants, including missense mutations (FCGR2A H131R and FCGR3A V176F) that decrease their binding affinity to human IgG and affect the clearance of immune complexes [8,18,21,23-25]. Two missense mutations have been suggested to confer the increased risk for SLE $[18,24,25]$ in spite of inconsistent results in different populations $[26,27]$

Type I interferon has been implicated in SLE pathophysiology, and there have been several genes identified in the related pathway [21]. The overproduction of type I interferon can promote the maturation of dendritic cells, and the expression of proinflammatory cytokines and chemokines, leading to diverse effects on immune functions including the activation of autoreactive B cells and $\mathrm{T}$ cells, the production of autoantibodies, and loss of self-tolerance $[28,29]$.

TNF $\alpha$-induced protein 3 (TNFAIP3), also known as the zinc-finger A20 protein, is a ubiquitin-editing enzyme that restricts both TNF receptor and TLRinduced NF- $\kappa \mathrm{B}$ signals, and therefore is required for effective termination of NF- $\kappa \mathrm{B}$-mediated proinflammatory responses [30-32]. In recent GWA studies, genetic variants in the TNFAIP3 gene have been identified as contributing to the genetic risk of SLE in both European and Asian populations $[12,15,19]$. These variants include a potential causal SNP (rs2230926), which was suggested to reduce the ability of A20 to attenuate NF- $\kappa$ B signaling, resulting in a high level of type I interferon production $[15,33]$.

An important category of innate immune receptors, TLRs can discriminate self-derived DNA from microbederived DNA. However, they can also be activated by host-derived nucleic acid; for example, nucleic acid-containing autoantibody complexes or apoptotic or necrotic cell debris, the deposition of which is a predominant feature of SLE disease $[34,35]$. Of the TLRs, TLR9 was suggested to be involved in the pathogenesis of SLE because its aberrant activation may lead to the production of type I interferon [28].

Another gene related to the DNA-recognition-activated type I interferon response pathway is the 3' repair exonuclease 1 (TREX1). Normally, TREX1 prevents activation of cell-intrinsic type I interferon response by digesting cytosolic single-stranded DNA [36]. When TREX1 is mutated, however, it will cause the activation of type I interferon and subsequent autoimmunity. Previous studies have shown that mutations in TREX1 were associated with SLE [37]; however, the association was inconsistent in different populations [38].

We conducted a case-control association study in 564 cases and 504 controls from Yunnan province of southwestern China. We screened a total of seven candidate genes, including FCGR3A, FCGR2A, TNFAIP3, TLR9, TREX1 and the two newly identified susceptibility genes E26 transformation-specific 1 (ETS1) and TNFAIP3 interacting protein 1 (TNIP1). The association of ETS1 and TNIP1 with SLE was first reported in a recent Chinese GWA study [19]. TNIP1 interacts with TNFAIP3 and may play a role in NF- $\kappa \mathrm{B}$ inhibition together with TNFAIP3. The association of TNIP1 with SLE was also reported in the GWA study of Europeans [17]. ETS1 is a member of the E26 transformation-specific family of transcription factors that control a wide variety of cellular processes including immune cell differentiation and development, and was shown to negatively regulate $\mathrm{T}$ helper type 17 (Th17) cell differentiation and terminal differentiation of B cells $[39,40]$. A recent study in Asian populations demonstrated that reduced expression of ETS1 may play a role in SLE pathogenesis through increased differentiation and activity of both plasma cells and Th17 cells [20]. Although the two new susceptibility genes were identified through GWA studies in large number of cases, disease susceptibility has to be validated via replication study in more populations. The aim of this replication study is to test the susceptibility of the seven genes for SLE in a southwestern Chinese population.

\section{Materials and methods Patients and controls}

A total of 564 unrelated SLE patients $(89.8 \%$ female and mean age $37.1 \pm 13.6)$ and 504 unrelated healthy controls $(87.5 \%$ female and mean age $39.3 \pm 13.2)$ were recruited from 1999 to 2010 in Kunming, Yunnan, China. All SLE patients fulfilled the American College of Rheumatology classification criteria [1,2]. We obtained the detailed clinical data from 450 out of the 564 SLE patients, which were used for the stratified analysis. The protocol of the present study was approved by the Institutional Review Board of Kunming Institute of Zoology, Chinese Academy of Sciences. Informed consent was obtained from all participants. 


\section{SNP selection}

SNP selection was based on the published data [15,17-20,23-25,37,41] and the linkage disequilibrium patterns in the Han Chinese from Beijing plus Japanese population in the HapMap database (Figure S1 in Additional file 1). The SNPs rs11581823 and rs7539036 were selected for FCGR3A; rs10800309, rs4656308 and rs1801274 for FCGR2A; rs5029924, rs5029936, rs5029937, rs2230926 and rs610604 for TNFAIP3; rs187084, rs352140 and rs352162 for TLR9; rs2242150 and rs3135941 for TREX1; rs6590330 and rs4937333 for ETS1; and rs13168551, rs7708392 and rs10036748 for TNIP1. A total of 20 SNPs were selected (Table 1).

\section{Genotyping}

Venous blood was collected from all participants, and genomic DNA was extracted using the standard phenolchloroform method. DNA samples of the cases and controls were randomly distributed in the DNA plates. All of the selected SNPs were genotyped by the SNaPShot method on an ABI 3130 genetic analyzer (Applied Biosystems, Foster City, CA, USA). The SNP genotype callings were automatically performed using ABI GeneMapper 4.0 (Applied Biosystems, Foster City, CA, USA) and verified manually. To ensure the accuracy of genotyping, we conducted bidirectional sequencing on 32 randomly selected individuals; no genotyping errors were found. The genotyping success rate for the selected SNPs is $96.7 \%$.

\section{Statistical analysis}

Hardy-Weinberg equilibrium and allelic and genotypic associations were performed in 564 cases and 504 controls using PLINK 1.07 [42]. We also conducted the association analysis in females only by considering sex as a covariate. The resulting $P$ values were corrected by applying the Bonferroni criterion, in which $P$ values were multiplied by the number of tested SNPs to produce the Bonferroni-corrected $P$ values. The power to detect association was calculated using the CaTs program $[43,44]$, based on the minor allele frequency of each SNP in our case-control samples and the effect size calculated in the allelic association analysis. The prevalence of 0.06 was used according to the literature data $[45,46]$.

Table 1 SNP association analysis of the 18 SNPs in all cases and controls

\begin{tabular}{|c|c|c|c|c|c|c|c|}
\hline \multirow[t]{2}{*}{ Gene and SNP } & \multirow[t]{2}{*}{ Position $^{a}$} & \multirow[t]{2}{*}{ Minor allele } & \multicolumn{2}{|c|}{ Minor allele frequency } & \multirow[t]{2}{*}{$P$ value } & \multirow[t]{2}{*}{ Corrected $P$ value ${ }^{\mathrm{b}}$} & \multirow[t]{2}{*}{ Odds ratio (95\% confidence interval) } \\
\hline & & & Case & Control & & & \\
\hline \multicolumn{8}{|l|}{$\overline{F C G R 3 A}$} \\
\hline rs11581823 & 1:161517384 & C & 0.0830 & 0.0975 & 0.28 & & $0.84(0.62$ to 1.14$)$ \\
\hline rs7539036 & 1:161512731 & $\mathrm{T}$ & 0.0580 & 0.0714 & 0.25 & & $0.80(0.56$ to 1.14$)$ \\
\hline \multicolumn{8}{|l|}{ FCGR2A } \\
\hline rs4656308 & 1:161478751 & C & 0.1602 & 0.1456 & 0.36 & & $1.12(0.88$ to 1.42$)$ \\
\hline rs1801274 & 1:161479745 & G & 0.3565 & 0.34 & 0.43 & & $1.08(0.90$ to 1.29$)$ \\
\hline \multicolumn{8}{|l|}{ TNFAIP3 } \\
\hline rs5029924 & 6:138187498 & $\mathrm{T}$ & 0.0817 & 0.0470 & 0.0017 & 0.030 & $1.80(1.25$ to 2.61$)$ \\
\hline rs5029937 & $6: 138195151$ & $\mathrm{~T}$ & 0.0812 & 0.0448 & 0.0006 & 0.012 & 1.88 (1.30 to 2.73$)$ \\
\hline rs2230926 & 6:138196066 & G & 0.0811 & 0.0448 & 0.0007 & 0.012 & 1.88 (1.30 to 2.72$)$ \\
\hline rs610604 & 6:138199417 & G & 0.0989 & 0.0984 & 1.00 & & $1.00(0.75$ to 1.34$)$ \\
\hline \multicolumn{8}{|l|}{ TLR9 } \\
\hline rs187084 & $3: 52261031$ & C & 0.3773 & 0.3722 & 0.82 & & 1.02 (0.85 to 1.22$)$ \\
\hline rs352140 & 3:52256697 & A & 0.3686 & 0.3635 & 0.82 & & 1.02 (0.86 to 1.22$)$ \\
\hline rs352162 & 3:52252969 & G & 0.3850 & 0.3770 & 0.72 & & 1.04 (0.87 to 1.24$)$ \\
\hline \multicolumn{8}{|l|}{ TREX1 } \\
\hline rs 2242150 & $3: 48505964$ & A & 0.3535 & 0.3340 & 0.35 & & $1.09(0.91$ to 1.31$)$ \\
\hline rs3135941 & $3: 48507667$ & $C$ & 0.0326 & 0.0392 & 0.47 & & $0.82(0.52$ to 1.32$)$ \\
\hline \multicolumn{8}{|l|}{ ETS1 } \\
\hline rs6590330 & $11: 128311059$ & A & 0.4258 & 0.3086 & $3.0 \times 10^{-8}$ & $5.5 \times 10^{-7}$ & 1.66 (1.39 to 1.99$)$ \\
\hline rs4937333 & $11: 128330520$ & $\mathrm{~T}$ & 0.4814 & 0.3652 & $9.3 \times 10^{-8}$ & $1.7 \times 10^{-6}$ & 1.61 (1.35 to 1.92$)$ \\
\hline \multicolumn{8}{|l|}{ TNIP1 } \\
\hline rs13168551 & 5:150462638 & $\mathrm{T}$ & 0.2211 & 0.2505 & 0.14 & & 0.85 (0.69 to 1.05$)$ \\
\hline rs7708392 & 5:150457485 & G & 0.2132 & 0.2587 & 0.02 & 0.39 & 0.78 (0.63 to 0.96$)$ \\
\hline rs10036748 & 5:150458146 & C & 0.2196 & 0.2552 & 0.08 & & $0.82(0.66$ to 1.02$)$ \\
\hline
\end{tabular}

Bold data are significant. ${ }^{\mathrm{a} G e n o m i c}$ positions from NCBI Genome Build 37.1 (GRCh37) [56]. ${ }^{\mathrm{b}} \mathrm{P}$ values calculated by Fisher's exact test and then corrected by the Bonferroni criterion. 
To further investigate whether certain SNPs exclusively confer the genetic risk in one or more specific subphenotypes and to discover potential association of certain SNPs with SLE disease, stratified analysis based on onset age (age 27 was used, according to the literature data [45-47]) and 11 American College of Rheumatology-defined clinical subphenotypes were conducted, in which association was assessed by comparing allele and genotype distributions between patients with a certain subphenotype and controls, between patients without the subphenotype and controls, and between patients with and without the subphenotype (paired patient groups). Often, the associations can be observed in both of certain paired patient groups. We therefore compared the frequencies of minor alleles in controls and paired patient groups (assuming that minor alleles should be significantly enriched in a certain subphenotype if they really contribute to the subphenotype pathogenesis), and calculated the conditional frequencies of onset age and other subphenotypes in the paired patient groups to understand their compositions and to re-evaluate certain associations detected in the stratified analysis.

\section{Results}

All SNPs were in Hardy-Weinberg equilibrium in both cases and controls $(P>0.05$ after Bonferroni correction) except for rs10800309 in controls $\left(P=1.69 \times 10^{-9}\right)$ and rs5029936 in cases $\left(P=8.17 \times 10^{-4}\right)$ - these two SNPs were therefore excluded, resulting in a total of 18 SNPs for subsequent association analysis. According to the obtained clinical information, a total of 450 SLE patients have the complete data for the 11 American College of Rheumatology clinical subphenotypes, including malar rash $(72.9 \%)$, discoid rash $(16.2 \%)$, photosensitivity (17.3\%), oral ulcers $(17.1 \%)$, arthritis $(75.8 \%)$, serositis (33.8\%), renal disorder (60.7\%), neurologic disorder (11.1\%), hematologic disorder (82.2\%), immunologic disorder (75.6\%) and antinuclear antibody (97.1\%).

\section{Association of TNFAIP3, ETS1 and TNIP1 with SLE}

The result of allelic association for each SNP is shown in Table 1. A total of six SNPs were found to be significantly related to $\operatorname{SLE}(P<0.05$, Table 1$)$, and five of them remained significant after Bonferroni correction, including three SNPs in TNFAIP3 (rs5029924, rs5029937 and rs2230926) and two SNPs in ETS1 (rs6590330 and rs4937333). The SNP rs7708392 in TNIP1 showed weak association $(P=0.0211$, uncorrected), but became nonsignificant after correction. Association analysis using the genotype data generated similar results (Table $\mathrm{S} 1$ in Additional file 1). The results remained the same when only females were considered (data not shown).

\section{Lack of association of FCGR3A, FCGR2A, TLR9 and TREX1 with SLE}

Significant association with SLE was not observed in the selected SNPs for FCGR3A, FCGR2A, TLR9 and TREX1 in either the allelic or the genotypic association analyses (Table 1; see also Table S1 in Additional file 1). The same results were obtained when only considering the females (data not shown).

The power calculation was performed (Table S2 in Additional file 1) to detect false-positive and false-negative association results. For SNPs rs5029924, rs5029937 and rs2230926 in TNFAIP3, rs6590330 and rs4937333 in ETS1, and rs7708392 in TNIP1, the sample size of this study showed relatively high power (76 to $100 \%$ ) to detect association when allowing a false-positive rate of 0.05; however, the sample size showed rather low power for the other SNPs (0 to 57\%). It is noteworthy that SNPs rs610604 (in TNFAIP3), rs187084, rs352140 and rs352162 (in TLR9) showed a rather low effect size (odds ratio $(\mathrm{OR})=1.00$ to 1.04 ), implying that they have almost no or a rather weak contribution to SLE pathogenesis in the Chinese population. As for the SNPs in FCGR2A and TREX1, although no significant association was detected (probably due to the small sample size), the same trend was observed as reported in previous studies [14,18,37].

\section{Stratified analysis}

As shown in Figure 1 (see also Table S3 in Additional file 1), the SNPs rs5029924, rs5029937 and rs2230926 in TNFAIP3 were observed to be significantly associated with onset age and most of the clinical subphenotypes, including malar rash, arthritis, serositis, neurologic disorder, hematologic disorder, immunologic disorder and antinuclear antibody $(\mathrm{OR}=1.67$ to $3.18, P=0.021$ to 0.001). For ETS1, SNPs rs6590330 and rs4937333 showed significant association with onset age and multiple clinical subphenotypes, including malar rash, photosensitivity, arthritis, serositis, renal disorder, hematologic disorder, immunologic disorder and antinuclear antibody $\left(\mathrm{OR}=1.50\right.$ to $1.98, P=0.003$ to $\left.1.9 \times 10^{-7}\right)$. For TNIP1, the SNP rs7708392 was also observed to be associated with onset age as well as several subphenotypes, including malar rash, renal disorder, immunologic disorder and antinuclear antibody $(\mathrm{OR}=0.75$ to $0.76, P$ $=0.017$ to 0.043$)$. In addition, the minor allele (rs3135941C) in TEX1 showed a weak association with the subphenotype of neurologic disorder (with a zero frequency in this subphenotype, $P=0.042$ ). The genotypic analysis with the subphenotypes generated similar results (Table S4 in Additional file 1).

As expected, certain SNPs also showed significance in both of the paired patient groups (Figure 1; see also Tables S3 and S4 in Additional file 1). Significance was 


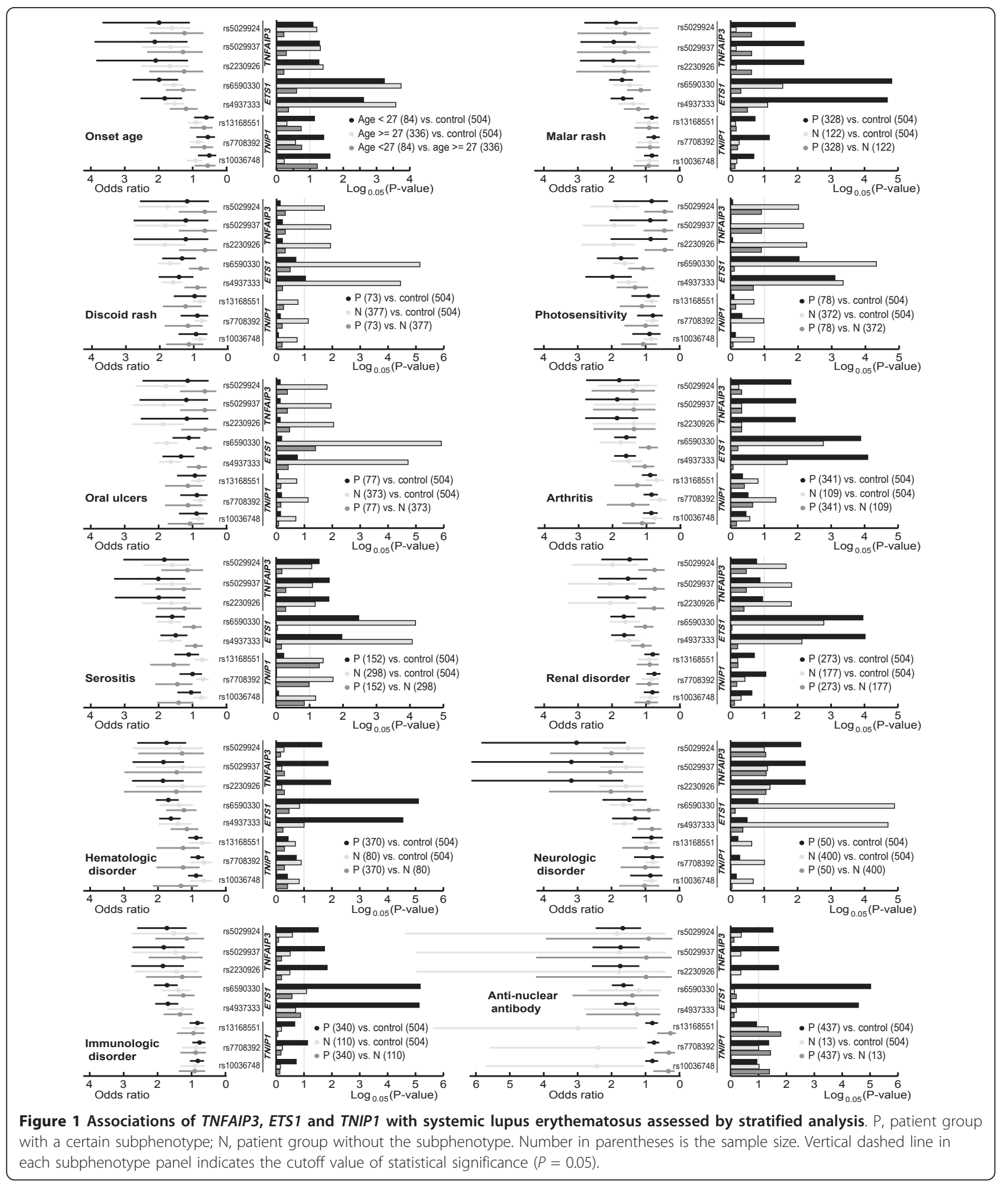

observed for rs5029924, rs5029937 and rs2230926 (TNFAIP3) in the paired patient groups of onset age and subphenotypes of serositis and neurologic disorder; for rs6590330 and rs4937333 (ETS1) in the paired patient groups of onset age and subphenotypes of malar rash, photosensitivity, arthritis, serositis and renal disorder; and for rs7708392 (TNIP1) in the paired patient groups of antinuclear antibody (Figure 1). Interestingly, 
SNPs rs6590330 and rs4937333 (ETS1) showed significance in the patient groups without the subphenotypes of oral ulcers and neurologic disorder when compared with the patient groups with these subphenotypes.

To discern between true and false associations, we compared the frequency distribution of the minor allele (only for TNFAIP3, ETS1 and TNIP1) in controls and the paired patient groups based on ORs (Figure 1) and compared the composition of these paired patient groups by calculating the conditional frequencies of onset age and other subphenotypes (Figure 2). Risk alleles of TNFAIP3 and ETS1 were found to be significantly enriched in subphenotypes of malar rash, arthritis, hematologic, neurologic and subphenotype

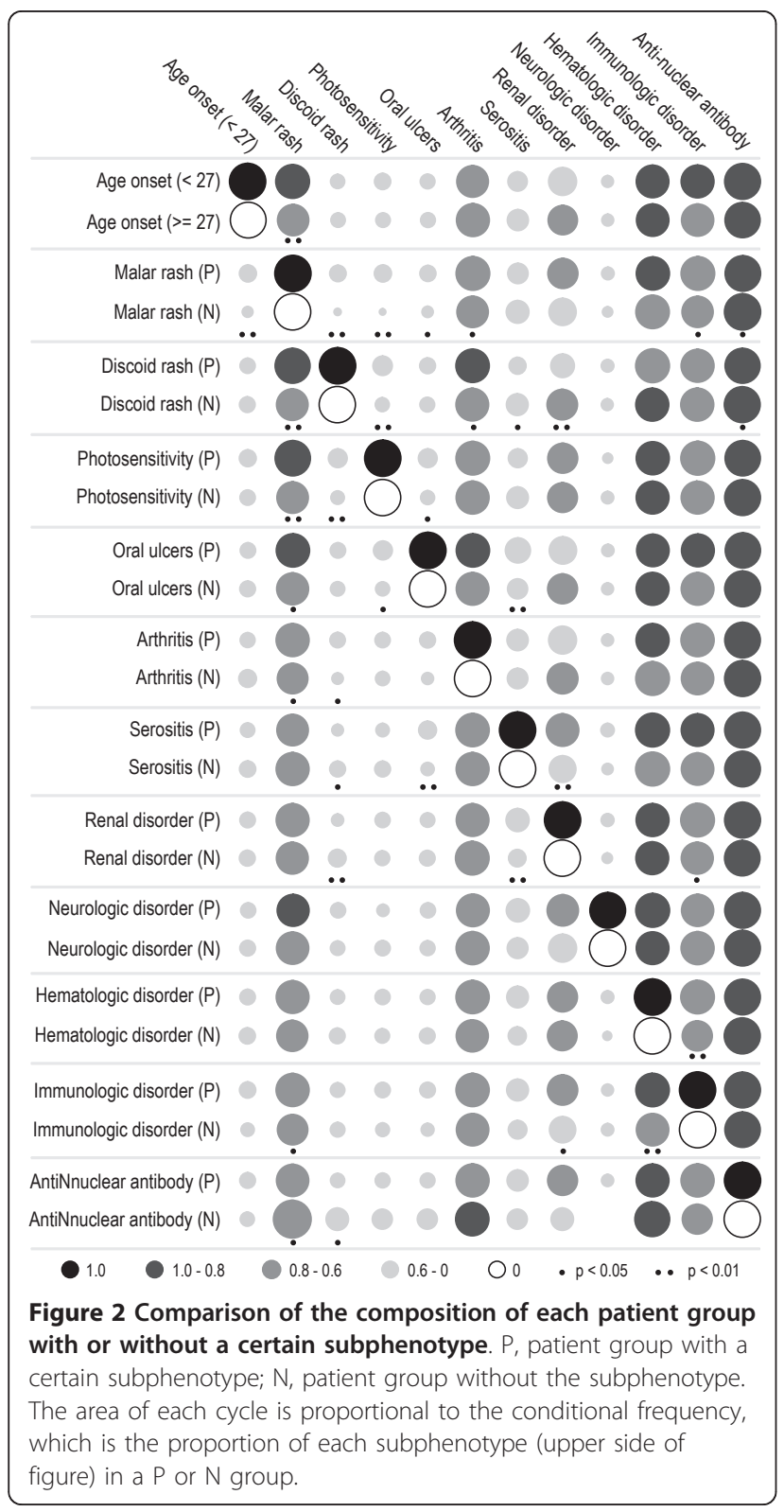

antinuclear antibody - with the highest OR when comparing the patient group with the subphenotype with the controls, and the lowest OR when comparing the patient group without the subphenotype with the controls. Likewise, protective alleles of TNIP1 were found to have a similar enrichment pattern when considering onset age. We believe that these associations are probably true positive. As for the comparison of the composition of paired groups shown in Figure 2, most of them are similar. Although only a few subphenotypes showed the difference of conditional frequency, they would help excluding the false positive. For example, TNFAIP3 showed significance and the enrichment of minor allele in both of the paired groups for onset age, which have different frequencies in malar rash-positive patients $(P<$ $0.01)$. Since the malar rash subphenotype was significantly related with TNFAIP3, its decreased frequency in patients aged $\geq 27$ reduced the corresponding effect size, suggesting that the association of TNFAIP3 with onset age was probably caused by other subphenotypes associated with TNFAIP3. Another example is that ETS1 showed significance and a larger effect size in patient groups without discoid rash, which was probably due to the significantly increased frequency of antinuclear antibody (Figure 2).

\section{Discussion}

Among the seven genes tested for SLE susceptibility, three (TNFAIP3, TNIP1 and ETS1) were successfully replicated for the associations. Consistent with recent studies [19,20,48-50], rs2230926 in TNFAIP3, rs7708392 in TNIP1, and rs4937333 and rs6590330 in ETS1 showed significant associations with SLE (Table 1; see also Table S1 in Additional file 1). The SNP rs2230926 in TNFAIP3 is a nonsynonymous variant, and the risk allele (rs2230926G) was suggested to downregulate the expression and activity of inhibiting the TNF-induced NF- $\kappa$ B activity of A20 protein [15]. A recent study demonstrated that the functional variant TT $>$ A was significantly associated with SLE in European and Korean populations, leading to reduced TNFAIP3 mRNA and A20 protein expression [33]. Similarly, a functional SNP (rs1128334), tightly linked with rs6590330 and located in the 3' UTR of ETS1, was significantly associated with lower expression of ETS1 in SLE patients ( $P$ $<0.0001)$ [20]. Since ETS1 is a negative regulator for the differentiation of both Th17 cells and B cells, the decreased expression of ETS1 possibly contributes to the SLE pathogenesis through the increased differentiation and activity of both plasma cells and Th17 cells $[20,39,40]$. Combined with the reported data and the power calculation (Table S2 in Additional file 1), our results support TNFAIP3 and ETS1 as probable common genetic risk factors for SLE in different 
populations, highlighting the importance of two biological pathways: type I interferon (involving TNFAIP3) and immune signal transduction in lymphocytes (involving ETS1).

The observed association for TNIP1 in our samples was weak. This gene was recently identified in European (rs7708392) and Chinese (rs10036748) populations via GWA studies $[17,19]$, and its association with SLE has been replicated in Japanese (rs7708392) and Han Chinese (rs10036748) populations [48,51]. In our samples, the $\mathrm{G}$ allele of rs7708392 showed a protective effect for SLE (allele frequency in SLE: $21.3 \%$, control: $25.9 \%$; OR $=0.78,95 \%$ confidence interval $=0.63$ to $0.96, P=$ 0.02 ), which is similar to the results reported in a Japanese population [48]. Interestingly, the $\mathrm{G}$ allele frequencies of rs7708392 are highly different between Asian $(\sim 30 \%)$ and European $(\sim 70 \%)$ populations, suggesting genetic heterogeneity at this locus among different populations. Although the selected SNPs in TNIP1 showed weak associations with SLE, they have a very similar minor allele frequency distribution to a recent Chinese GWA study (rs10036748: 20.5\% in cases and $25.4 \%$ in controls, OR $=0.80$ ) [19]. The power calculation (76\%) suggested the reliability of the association of TNIP1 with SLE and also indicated that a larger sample size could help further confirm the role of TNIP1 in Chinese SLE patients.

We did not replicate the associations of the other four genes (FCGR3A, FCGR2A, TLR9 and TREX1) in our samples (Table 1; see also Table $\mathrm{S} 1$ in Additional file 1). FCGR3A and FCGR2A are involved in the clearance of immune complexes, and TLR9 and TREX1 may promote the production of type I interferon $[28,36]$. The previously proposed SLE susceptibility of these four genes was inconsistent among different populations $[26,27,38,41]$. No association was reported in Chinese, Korean and Japanese populations [26,38,41,52], although weak associations of several SNPs were observed; for example, rs396991 in FCGR3A [53], rs1801274 in FCGR2A [54], rs352140 in TLR9 [55] and the TREX1 polymorphism -20260G > C [38]. Hence, whether these four genes contribute to SLE susceptibility calls for more studies, as implied in the power calculation results (Table S2 in Additional file 1).

In the stratified analysis, TNFAIP3, ETS1 and TNIP1 remained the significant associations with SLE (Figure 1; see also Tables S3 and S4 in Additional file 1). TNFAIP3 and ETS1 were significantly associated with most subphenotypes, but none of them showed association with oral ulcers (Figure 1). As for TNIP1, the minor allele of rs7708392 was associated with a few SLE subphenotypes including malar rash, renal disorder and antinuclear antibody, which were also observed in the Japanese population [48]. It should be noted among several subphenotypes with high frequencies that malar rash, hematologic disorder, immunologic disorder and antinuclear antibody co-occurred in $48 \%$ of patients, and the last three subphenotypes showed a higher frequency of co-occurrence $(62.67 \%)$. These features may cause false-positive associations as long as one of these cooccurred subphenotypes contributes greatly to the pathogenesis of SLE. We should therefore be cautious in interpreting the association results of SLE subphenotypes, and functional data are needed to confirm the contributions of the risk genes to the SLE pathogenesis.

\section{Conclusions}

Our replication study confirmed the association of TNFAIP3, ETS1 and TNIP1 with SLE susceptibility in a southwestern Chinese population. In particular, TNFAIP3 and ETS1 are probably common genetic risk factors for SLE among Asian populations, and they contribute to most of the clinical subphenotypes of SLE, supporting the critical roles of two recently proposed biological pathways: type I interferon and immune signal transduction in lymphocytes in the pathogenesis of SLE.

\section{Additional material}

Additional file 1: SNP selection, analysis and distribution data

Figure S1 shows gene structures and linkage disequilibrium plots calculated by Haploview 4.2 based on the HapMap Phase II dataset for the Han Chinese from Beijing plus Japanese (CHB + JPT) population. Table S1 presents genotype association analysis of the 18 SNPs in all cases and controls. Table S2 presents power analysis of the 18 SNPs in the present study. Table S3 presents the allele frequency distribution of the 18 SNPs in controls and different subphenotypes. Table \$4 presents the genotype distribution of the 18 SNPs in controls and different subphenotypes.

\section{Abbreviations}

ETS1: E26 transformation-specific 1; FCGR: FCy receptor; GWA: genome-wide association; NF: nuclear factor; OR: odds ratio; SLE: systemic lupus

erythematosus; SNP: single nucleotide polymorphism; Th: T-helper type; TLR: toll-like receptor; TNF: tumor necrosis factor; TNFAIP3: TNFa-induced protein 3; TNIP1: TNFAIP3 interacting protein 1; TREX1: the 3' repair exonuclease 1; UTR: untranslated region.

\section{Acknowledgements}

The authors are grateful to all participants involved in the present study. They thank Hui Zhang for technical assistance. The study was supported by the extramural project of State Key Laboratory of Genetic Resources and Evolution (GREKF08-05), the National Natural Science Foundation of China (81060251), the joint project of Yunnan Provincial Department of Science \& Technology and Kunming Medical University (2008CD024), and the Knowledge Innovation Program of the Chinese Academy of Sciences (KSCX1-YW-R-45).

\section{Author details}

'State Key Laboratory of Genetic Resources and Evolution, Kunming Institute of Zoology, Chinese Academy of Sciences, Kunming, Yunnan 650223, China. 2Department of Dermatology and Rheumatology, The Affiliated Yan'an Hospital of Kunming Medical University, Kunming, Yunnan 650051, China. ${ }^{3}$ Kunming Medical University, Kunming, Yunnan 650500, China. ${ }^{4}$ State Key 
Laboratory of Molecular Developmental Biology, Institute of Genetics and Developmental Biology, Chinese Academy of Sciences, Beijing 100101, China. ${ }^{5}$ Graduate School of Chinese Academy of Sciences, Beijing 100080, China.

\section{Authors' contributions}

$L X, Z H, M R Z$ and $S B$ designed the study. ZH, LX, HL, CR, XK and QX carried out sample collection, DNA extraction and genotyping. $\mathrm{LX}, \mathrm{HL}$ and $\mathrm{CR}$ collected clinical information. ZH, LX, LM, MRZ and SB performed data analysis and wrote the manuscript. All authors read and approved the final manuscript.

\section{Competing interests}

The authors declare that they have no competing interests.

Received: 22 June 2011 Revised: 9 November 2011

Accepted: 16 November 2011 Published: 16 November 2011

\section{References}

1. Hochberg MC: Updating the American College of Rheumatology revised criteria for the classification of systemic lupus erythematosus. Arthritis Rheum 1997, 40:1725.

2. Tan EM, Cohen AS, Fries JF, Masi AT, McShane DJ, Rothfield NF, Schaller JG, Talal N, Winchester RJ: The 1982 revised criteria for the classification of systemic lupus erythematosus. Arthritis Rheum 1982, 25:1271-1277.

3. Alarcon-Segovia D, Alarcon-Riquelme ME, Cardiel MH, Caeiro F, Massardo L, Villa AR, Pons-Estel BA: Familial aggregation of systemic lupus erythematosus, rheumatoid arthritis, and other autoimmune diseases in 1,177 lupus patients from the GLADEL cohort. Arthritis Rheum 2005, 52:1138-1147.

4. Sestak AL, Shaver TS, Moser KL, Neas BR, Harley JB: Familial aggregation of lupus and autoimmunity in an unusual multiplex pedigree. $J$ Rheumatol 1999, 26:1495-1499.

5. Arnett FC, Shulman LE: Studies in familial systemic lupus erythematosus. Medicine (Baltimore) 1976, 55:313-322.

6. Reichlin M, Harley JB, Lockshin MD: Serologic studies of monozygotic twins with systemic lupus erythematosus. Arthritis Rheum 1992, 35:457-464.

7. Block SR, Winfield JB, Lockshin MD, D'Angelo WA, Christian CL: Studies of twins with systemic lupus erythematosus. A review of the literature and presentation of 12 additional sets. Am J Med 1975, 59:533-552.

8. Moser KL, Kelly JA, Lessard CJ, Harley JB: Recent insights into the genetic basis of systemic lupus erythematosus. Genes Immun 2009, 10:373-379.

9. Graham RR, Kozyrev SV, Baechler EC, Reddy MV, Plenge RM, Bauer JW, Ortmann WA, Koeuth T, Gonzalez Escribano MF, Pons-Estel B, Petri M, Daly M, Gregersen PK, Martin J, Altshuler D, Behrens TW, AlarconRiquelme ME: A common haplotype of interferon regulatory factor 5 (IRF5) regulates splicing and expression and is associated with increased risk of systemic lupus erythematosus. Nat Genet 2006, 38:550-555.

10. Remmers EF, Plenge RM, Lee AT, Graham RR, Hom G, Behrens TW, de Bakker PI, Le JM, Lee HS, Batliwalla F, Li W, Masters SL, Booty MG, Carulli JP, Padyukov L, Alfredsson L, Klareskog L, Chen WW, Amos Cl, Criswell LA, Seldin MF, Kastner DL, Gregersen PK: STAT4 and the risk of rheumatoid arthritis and systemic lupus erythematosus. N Engl J Med 2007, 357:977-986

11. Graham RR, Kyogoku C, Sigurdsson S, Vlasova IA, Davies LR, Baechler EC, Plenge RM, Koeuth T, Ortmann WA, Hom G, Bauer JW, Gillett C, Burtt N, Cunninghame Graham DS, Onofrio R, Petri M, Gunnarsson I, Svenungsson E, Ronnblom L, Nordmark G, Gregersen PK, Moser K, Gaffney PM, Criswell LA, Vyse TJ, Syvanen AC, Bohjanen PR, Daly MJ, Behrens TW, Altshuler D: Three functional variants of IFN regulatory factor 5 (IRF5) define risk and protective haplotypes for human lupus. Proc Natl Acad Sci USA 2007, 104:6758-6763.

12. Graham RR, Cotsapas C, Davies L, Hackett R, Lessard CJ, Leon JM, Burtt NP, Guiducci C, Parkin M, Gates C, Plenge RM, Behrens TW, Wither JE, Rioux JD, Fortin PR, Graham DC, Wong AK, Vyse TJ, Daly MJ, Altshuler D, Moser KL, Gaffney PM: Genetic variants near TNFAIP3 on $6 \mathrm{q} 23$ are associated with systemic lupus erythematosus. Nat Genet 2008, 40:1059-1061.

13. Hom G, Graham RR, Modrek B, Taylor KE, Ortmann W, Garnier S, Lee AT, Chung SA, Ferreira RC, Pant PV, Ballinger DG, Kosoy R, Demirci FY, Kamboh MI, Kao AH, Tian C, Gunnarsson I, Bengtsson AA, RantapaaDahlqvist S, Petri M, Manzi S, Seldin MF, Ronnblom L, Syvanen AC,
Criswell LA, Gregersen PK, Behrens TW: Association of systemic lupus erythematosus with C8orf13-BLK and ITGAM-ITGAX. N Engl J Med 2008, 358:900-909.

14. Harley JB, Alarcon-Riquelme ME, Criswell LA, Jacob CO, Kimberly RP, Moser KL, Tsao BP, Vyse TJ, Langefeld CD, Nath SK, Guthridge JM, Cobb BL, Mirel DB, Marion MC, Williams AH, Divers J, Wang W, Frank SG, Namjou B, Gabriel SB, Lee AT, Gregersen PK, Behrens TW, Taylor KE, Fernando M, Zidovetzki R, Gaffney PM, Edberg JC, Rioux JD, Ojwang JO, et al: Genomewide association scan in women with systemic lupus erythematosus identifies susceptibility variants in ITGAM, PXK, KIAA1542 and other loci. Nat Genet 2008, 40:204-210.

15. Musone SL, Taylor KE, Lu TT, Nititham J, Ferreira RC, Ortmann W, Shifrin N, Petri MA, Kamboh MI, Manzi S, Seldin MF, Gregersen PK, Behrens TW, Ma A, Kwok PY, Criswell LA: Multiple polymorphisms in the TNFAIP3 region are independently associated with systemic lupus erythematosus. Nat Genet 2008, 40:1062-1064.

16. Kozyrev SV, Abelson AK, Wojcik J, Zaghlool A, Linga Reddy MV, Sanchez E, Gunnarsson I, Svenungsson E, Sturfelt G, Jonsen A, Truedsson L, PonsEstel BA, Witte T, D'Alfonso S, Barizzone N, Danieli MG, Gutierrez C, Suarez A, Junker P, Laustrup H, Gonzalez-Escribano MF, Martin J, Abderrahim H, Alarcon-Riquelme ME: Functional variants in the B-cell gene BANK1 are associated with systemic lupus erythematosus. Nat Genet 2008, 40:211-216.

17. Gateva V, Sandling JK, Hom G, Taylor KE, Chung SA, Sun X, Ortmann W, Kosoy R, Ferreira RC, Nordmark G, Gunnarsson I, Svenungsson E, Padyukov L, Sturfelt G, Jonsen A, Bengtsson AA, Rantapaa-Dahlqvist S, Baechler EC, Brown EE, Alarcon GS, Edberg JC, Ramsey-Goldman R, McGwin G Jr, Reveille JD, Vila LM, Kimberly RP, Manzi S, Petri MA, Lee A, Gregersen PK, et al: A large-scale replication study identifies TNIP1, PRDM1, JAZF1, UHRF1BP1 and IL10 as risk loci for systemic lupus erythematosus. Nat Genet 2009, 41:1228-1233.

18. Graham RR, Hom G, Ortmann W, Behrens TW: Review of recent genomewide association scans in lupus. J Intern Med 2009, 265:680-688.

19. Han JW, Zheng HF, Cui Y, Sun LD, Ye DQ, Hu Z, Xu JH, Cai ZM, Huang W, Zhao GP, Xie HF, Fang H, Lu QJ, Li XP, Pan YF, Deng DQ, Zeng FQ, Ye ZZ, Zhang XY, Wang QW, Hao F, Ma L, Zuo XB, Zhou FS, Du WH, Cheng YL, Yang JQ, Shen SK, Li J, Sheng YJ, et al: Genome-wide association study in a Chinese Han population identifies nine new susceptibility loci for systemic lupus erythematosus. Nat Genet 2009, 41:1234-1237.

20. Yang W, Shen N, Ye DQ, Liu Q, Zhang Y, Qian XX, Hirankarn N, Ying D, Pan HF, Mok CC, Chan TM, Wong RW, Lee KW, Mok MY, Wong SN, Leung AM, Li XP, Avihingsanon Y, Wong CM, Lee TL, Ho MH, Lee PP, Chang YK, Li PH, Li RJ, Zhang L, Wong WH, Ng IO, Lau CS, Sham PC, et al: Genome-wide association study in Asian populations identifies variants in ETS1 and WDFY4 associated with systemic lupus erythematosus. PLOS Genet 2010, 6:e1000841.

21. Harley IT, Kaufman KM, Langefeld CD, Harley JB, Kelly JA: Genetic susceptibility to SLE: new insights from fine mapping and genome-wide association studies. Nat Rev Genet 2009, 10:285-290.

22. Kaiser R, Criswell LA: Genetics research in systemic lupus erythematosus for clinicians: methodology, progress, and controversies. Curr Opin Rheumatol 2010, 22:119-125.

23. Salmon JE, Millard S, Schachter LA, Arnett FC, Ginzler EM, Gourley MF, Ramsey-Goldman R, Peterson MG, Kimberly RP: Fcy RIIA alleles are heritable risk factors for lupus nephritis in African Americans. J Clin Invest 1996, 97:1348-1354.

24. Karassa FB, Trikalinos TA, Ioannidis JP: Role of the Fcy receptor lla polymorphism in susceptibility to systemic lupus erythematosus and lupus nephritis: a meta-analysis. Arthritis Rheum 2002, 46:1563-1571.

25. Edberg JC, Langefeld CD, Wu J, Moser KL, Kaufman KM, Kelly J, Bansal V, Brown WM, Salmon JE, Rich SS, Harley JB, Kimberly RP: Genetic linkage and association of Fcy receptor IIIA (CD16A) on chromosome 1q23 with human systemic lupus erythematosus. Arthritis Rheum 2002, 46:2132-2140.

26. Yap SN, Phipps ME, Manivasagar M, Tan SY, Bosco JJ: Human Fcy receptor IIA (FcYRIIA) genotyping and association with systemic lupus erythematosus (SLE) in Chinese and Malays in Malaysia. Lupus 1999, 8:305-310.

27. Karassa FB, Trikalinos TA, loannidis JP: The Fcy RIIIA-F158 allele is a risk factor for the development of lupus nephritis: a meta-analysis. Kidney Int 2003, 63:1475-1482. 
28. Ardoin SP, Pisetsky DS: Developments in the scientific understanding of lupus. Arthritis Res Ther 2008, 10:218.

29. Kalliolias GD, Ivashkiv LB: Overview of the biology of type I interferons. Arthritis Res Ther 2010, 12(Suppl 1):S1.

30. Hitotsumatsu O, Ahmad RC, Tavares R, Wang M, Philpott D, Turer EE, Lee BL, Shiffin N, Advincula R, Malynn BA, Werts C, Ma A: The ubiquitinediting enzyme A20 restricts nucleotide-binding oligomerization domain containing 2-triggered signals. Immunity 2008, 28:381-390.

31. Wertz IE, O'Rourke KM, Zhou H, Eby M, Aravind L, Seshagiri S, Wu P, Wiesmann C, Baker R, Boone DL, Ma A, Koonin EV, Dixit VM: Deubiquitination and ubiquitin ligase domains of A20 downregulate NFkappaB signalling. Nature 2004, 430:694-699.

32. Boone DL, Turer EE, Lee EG, Ahmad RC, Wheeler MT, Tsui C, Hurley P, Chien M, Chai S, Hitotsumatsu O, McNally E, Pickart C, Ma A: The ubiquitinmodifying enzyme A20 is required for termination of Toll-like receptor responses. Nat Immunol 2004, 5:1052-1060.

33. Adrianto I, Wen F, Templeton A, Wiley G, King JB, Lessard CJ, Bates JS, Hu Y, Kelly JA, Kaufman KM, Guthridge JM, Alarcon-Riquelme ME, Anaya JM, Bae SC, Bang SY, Boackle SA, Brown EE, Petri MA, Gallant C, RamseyGoldman R, Reveille JD, Vila LM, Criswell LA, Edberg JC, Freedman BI, Gregersen PK, Gilkeson GS, Jacob CO, James JA, Kamen DL, et al: Association of a functional variant downstream of TNFAIP3 with systemic lupus erythematosus. Nat Genet 2011, 43:253-258.

34. Means TK, Latz E, Hayashi F, Murali MR, Golenbock DT, Luster AD: Human lupus autoantibody-DNA complexes activate DCs through cooperation of CD32 and TLR9. J Clin Invest 2005, 115:407-417.

35. Saitoh S, Miyake K: Regulatory molecules required for nucleotide-sensing Toll-like receptors. Immunol Rev 2009, 227:32-43.

36. Stetson DB, Ko JS, Heidmann T, Medzhitov R: Trex1 prevents cell-intrinsic initiation of autoimmunity. Cell 2008, 134:587-598.

37. Lee-Kirsch MA, Gong M, Chowdhury D, Senenko L, Engel K, Lee YA, de Silva U, Bailey SL, Witte T, Vyse TJ, Kere J, Pfeiffer C, Harvey S, Wong A, Koskenmies S, Hummel O, Rohde K, Schmidt RE, Dominiczak AF, Gahr M, Hollis T, Perrino FW, Lieberman J, Hubner N: Mutations in the gene encoding the $3^{\prime}-5$ ' DNA exonuclease TREX1 are associated with systemic lupus erythematosus. Nat Genet 2007, 39:1065-1067.

38. Hur JW, Sung YK, Shin HD, Park BL, Cheong HS, Bae SC: TREX1 polymorphisms associated with autoantibodies in patients with systemic lupus erythematosus. Rheumatol Int 2008, 28:783-789.

39. Bories JC, Willerford DM, Grevin D, Davidson L, Camus A, Martin P, Stehelin D, Alt FW: Increased T-cell apoptosis and terminal B-cell differentiation induced by inactivation of the Ets-1 proto-oncogene. Nature 1995, 377:635-638,

40. Gallant S, Gilkeson G: ETS transcription factors and regulation of immunity. Arch Immunol Ther Exp (Warsz) 2006, 54:149-163.

41. Ng MW, Lau CS, Chan TM, Wong WH, Lau YL: Polymorphisms of the tolllike receptor 9 (TLR9) gene with systemic lupus erythematosus in Chinese. Rheumatology (Oxford) 2005, 44:1456-1457.

42. Purcell S, Neale B, Todd-Brown K, Thomas L, Ferreira MA, Bender D, Maller J, Sklar P, de Bakker PI, Daly MJ, Sham PC: PLINK: a tool set for wholegenome association and population-based linkage analyses. Am J Hum Genet 2007, 81:559-575.

43. CaTs. [http://www.sph.umich.edu/csg/abecasis/CaTS/index.html].

44. Skol AD, Scott $L$, Abecasis $G R$, Boehnke M: Joint analysis is more efficient than replication-based analysis for two-stage genome-wide association studies. Nat Genet 2006, 38:209-213.

45. Osio-Salido E, Manapat-Reyes H: Epidemiology of systemic lupus erythematosus in Asia. Lupus 2010, 19:1365-1373.

46. Yang W, Zhao M, Hirankarn N, Lau CS, Mok CC, Chan TM, Wong RW, Lee KW, Mok MY, Wong SN, Avihingsanon Y, Lin IO, Lee TL, Ho MH, Lee PP, Wong WH, Sham PC, Lau YL: ITGAM is associated with disease susceptibility and renal nephritis of systemic lupus erythematosus in Hong Kong Chinese and Thai. Hum Mol Genet 2009, 18:2063-2070.

47. Yang W, Ng P, Zhao M, Hirankarn N, Lau CS, Mok CC, Chan TM, Wong RW, Lee KW, Mok MY, Wong SN, Avihingsanon Y, Lee TL, Ho MH, Lee PP, Wong WH, Lau YL: Population differences in SLE susceptibility genes: STAT4 and BLK, but not PXK, are associated with systemic lupus erythematosus in Hong Kong Chinese. Genes Immun 2009, 10:219-226.

48. Kawasaki A, Ito S, Furukawa H, Hayashi T, Goto D, Matsumoto I, Kusaoi M, Ohashi J, Graham RR, Matsuta K, Behrens TW, Tohma S, Takasaki Y, Hashimoto H, Sumida T, Tsuchiya N: Association of TNFAIP3 interacting protein 1, TNIP1 with systemic lupus erythematosus in a Japanese population: a case-control association study. Arthritis Res Ther 2010, 12 R174.

49. Shimane $K$, Kochi $Y$, Horita T, Ikari K, Amano H, Hirakata M, Okamoto A, Yamada R, Myouzen K, Suzuki A, Kubo M, Atsumi T, Koike T, Takasaki Y, Momohara S, Yamanaka H, Nakamura Y, Yamamoto K: The association of a nonsynonymous single-nucleotide polymorphism in TNFAIP3 with systemic lupus erythematosus and rheumatoid arthritis in the Japanese population. Arthritis Rheum 2010, 62:574-579.

50. Cai LQ, Wang ZX, Lu WS, Han JW, Sun LD, Du WH, Zhang SM, Zuo XB, Zhang XJ, Yang S: A single-nucleotide polymorphism of the TNFAIP3 gene is associated with systemic lupus erythematosus in Chinese Han population. Mol Biol Rep 2010, 37:389-394

51. He CF, Liu YS, Cheng YL, Gao JP, Pan TM, Han JW, Quan C, Sun LD, Zheng HF, Zuo XB, Xu SX, Sheng YJ, Yao S, Hu WL, Li Y, Yu ZY, Yin XY, Zhang XJ, Cui Y, Yang S: TNIP1, SLC15A4, ETS1, RasGRP3 and IKZF1 are associated with clinical features of systemic lupus erythematosus in a Chinese Han population. Lupus 2010, 19:1181-1186.

52. Hatta Y, Tsuchiya N, Ohashi J, Matsushita M, Fujiwara K, Hagiwara K, Juji T, Tokunaga K: Association of Fcy receptor IIIB, but not of Fcy receptor IIA and IIIA polymorphisms with systemic lupus erythematosus in Japanese. Genes Immun 1999, 1:53-60.

53. Li LH, Yuan H, Pan HF, Li WX, Li XP, Ye DQ: Role of the Fcy receptor IIIA-V/ F158 polymorphism in susceptibility to systemic lupus erythematosus and lupus nephritis: a meta-analysis. Scand J Rheumatol 2010, 39:148-154.

54. Song YW, Han CW, Kang SW, Baek HJ, Lee EB, Shin CH, Hahn BH, Tsao BP: Abnormal distribution of Fcy receptor type lla polymorphisms in Korean patients with systemic lupus erythematosus. Arthritis Rheum 1998, 41:421-426.

55. Xu CJ, Zhang WH, Pan HF, Li XP, Xu JH, Ye DQ: Association study of a single nucleotide polymorphism in the exon 2 region of toll-like receptor 9 (TLR9) gene with susceptibility to systemic lupus erythematosus among Chinese. Mol Biol Rep 2009, 36:2245-2248.

56. [http:/]

\section{doi:10.1186/ar3514}

Cite this article as: Zhong et al:: Replicated associations of TNFAIP3,

TNIP1 and ETS1 with systemic lupus erythematosus in a southwestern Chinese population. Arthritis Research \& Therapy 2011 13:R186.

\section{Submit your next manuscript to BioMed Central and take full advantage of:}

- Convenient online submission

- Thorough peer review

- No space constraints or color figure charges

- Immediate publication on acceptance

- Inclusion in PubMed, CAS, Scopus and Google Scholar

- Research which is freely available for redistribution 